Vol. 18 (2009): 388-401.

\title{
Evidence for the formation of Luvisols/Alfisols as a response to coupled pedogenic and anthropogenic influences in a clay soil in Finland
}

\author{
Markku Yli-Halla ${ }^{1}$, Delbert L. Mokma², Laura Alakukku ${ }^{4}$, Richard Drees ${ }^{3}$ and Larry P. Wilding ${ }^{3}$
}

${ }^{1}$ MTT Agrifood Research Finland, Soil and Plant Nutrition, Currently: Dept of Applied Chemistry and Microbiology, PO Box 27, University of Helsinki, FI-00014 Helsinki, Finland, e-mail: firstname.lastname@helsinki.fi

${ }^{2}$ Dept of Crop and Soil Sciences, Michigan State University, East Lansing, MI 48824, USA

${ }^{3}$ Dept of Soil and Crop Science, Texas A\&M University, College Station, TX-77843, USA

${ }^{4}$ MTT Agrifood Research Finland, Soil and Plant Nutrition,

Currently: Dept of Agrotechnology, PO Box 28, FI-00014 University of Helsinki, Finland.

\begin{abstract}
Clayey soils with a cryic soil temperature regime and an aquic soil moisture regime are extensive in southern Finland but they have rarely been pedogenically described. A pedon in a field that has been in agricultural use since the 17th century was characterized and features indicative of human-influenced pedogenic processes were identified. Owing to intensified agriculture, the soil has become drier than ever before. Natural shrink-swell and anthropogenic turbation processes had destroyed the rock structure to a depth of $72 \mathrm{~cm}$. Groundwater monitoring during nine years proved that in several years the soil had a chance to desiccate down to $150 \mathrm{~cm}$, resulting in wedge-shaped prisms and desiccation joint planes. The cracks and root channels serve as routes for clay translocation. Illuvial clay, observed in thin sections, had the maxima $(>1 \%)$ in the Btg (38-72 cm) and BCtg2 (112-140 cm) horizons, corresponding to the effective drainage depths during ditch drainage until 70 years ago and subsequent subsurface tile drainage, respectively. Seventy years of improved drainage seems to be sufficient to give rise to an argic/argillic horizon. This feature is likely manmade but, being irreversible, it must be taken into account in soil classification. In this climate, agriculture seems to influence pedogenesis strongly throughout the solum far below the plough layer. Luvisols (WRB) or Cryaqualfs (Soil Taxonomy) have not been documented in a clay soil in Finland or Sweden before.
\end{abstract}

Key-words: argic horizon, argillic horizon, bulk density, clay translocation, desiccation, drainage, groundwater level, micromorphology, pedogenesis, shrink-swell phenomenon, soil mineralogy 


\section{AGRICULTURAL AND FOOD SCIENCE}

Vol. 18 (2009): 388-401.

\section{Introduction}

Clayey soils are extensive and important for agriculture and urban development in southern Finland. Soils of the area have a cryic soil temperature regime (Yli-Halla and Mokma 1998) and an aquic soil moisture regime (Yli-Halla and Mokma 2001). In cool, humid climates, pedogenesis is likely quite slow. Therefore the Nordic clay soils have not been subjected to intensive research from the pedological perspective, except the acid sulphate soils. The influence of parent material on soils in these environments is very great, hence the national soil maps of the area traditionally reflect the parent materials.

The clay content of these soils usually increases with depth (e.g. Kirchmann 1991, Kirchmann and Eriksson 1993, Yli-Halla and Mokma 2001, Peltovuori et al. 2002). This feature can be caused by the different textural composition of the sedimentary parent material over time, since clay content correlates positively with the distance of the origin of the material and the depth of water during sedimentation. On the other hand, clay content can be influenced by clay translocation. In these marine sediments it is difficult to prove clay translocation based solely on clay content, because there are commonly lithological discontinuities in these materials (Mokma et al. 2000). Therefore, micromorphological methods are necessary to elucidate that clay eluviation and illuviation processes have taken place.

Direct evidence of illuvial clay has not been documented in the descriptions of clay soils formed after the Weichselian glaciation in Finland or Sweden. However, substantial concentrations of clay in Jokioinen, Finland have been observed in subsurface drainage waters, and most of it was thought to have originated from the Ap horizon (Uusitalo et al. 2001). Moreover, cultivated clay soils of Finland commonly have, immediately below the plough layer, a thin B horizon that is more light-colored (value and chroma 5/3) than the deeper horizons (4/1), indicating eluviation of substances. On this basis, Peltovuori et al. (2002) classified some of their experimental soils according to Soil Taxono- my as Aeric Cryaquepts. However, most clay soils of Finland have been classified as Typic Cryaquepts (Mokma et al. 2000, Yli-Halla and Mokma 2001). In the Geographical Soil Database of Europe, compiled according to the World Reference Base System (WRB), they appear to classify as Vertic Cambisols. Clay eluviation and illuviation have not been documented in the clayey soils of longterm field experiments in Sweden (e.g. Kirchmann 1991, Kirchmann and Eriksson 1993). However, argic/argillic horizons, and consequently Luvisols/ Alfisols, occur in Estonia (Reintam and Köster 2006) and Luvic Stagnosols in Norway (Nyborg and Solbakken 2008). At least in Østfold county, southeastern Norway, soils with argic horizons (Luvic Stagnosols and Epistagnic Albeluvisols) are reported to be the most common agricultural soils in the area (Nyborg et al. 2008).

Prerequisites of clay translocation are clay detachment and sufficient drying of the soil to allow the attachment of the eluviated clay particles onto the walls of micropores. Clay detachment is promoted by wetting of dry soil, low salt content of rain and snow-melt water and by soil physical disturbance (tillage), particularly autumn ploughing, which has been the traditional method of primary tillage in the cultivation of cereal crops in Finland. The impact of ploughing as compared to conservation tillage was demonstrated in a five-year study by Koskiaho et al. (2002) on a clay soil of Finland. It was documented that $230 \mathrm{~kg} \mathrm{ha}^{-1}$ of eluviated soil material were transported through drainage tile under the conventional tilled plot during the winter period, whereas only $160 \mathrm{~kg} \mathrm{ha}^{-1}$ were transported from the no-till plot. Further, it was shown by Turtola and Paajanen (1995) that annually up to $1300 \mathrm{~kg} \mathrm{ha}^{-1}$ of soil material were transported through the drainage tile from a clay soil of Jokioinen. Up to the late 19th century, wetness and poor drainage were considered major limitations for successful crop production in southern Finland (Soininen 1974, p. 113). However, currently clay soils of Finland are artificially drained to the depth of 100-120 cm and much more productive. In spite of the rather humid climate, irrigation often gives rise to substantial yield increases because of seasonal summer soil moisture stress in these soils 


\title{
AGRICULTURAL AND FOOD SCIENCE
}

\author{
Yli-Halla, M. et al. Luvisols/Alfosols in Finland
}

(e.g., Elonen 1967). The above studies suggest that agricultural anthropogenic activities have changed soil properties and may have had a significant influence on pedogenesis.

To put the clayey soils of Finland into the international context, ten soil profiles were morphologically investigated and chemically analyzed in 1997-2001 on the premises of MTT Agrifood Research Finland at Jokioinen in southwestern Finland. A toposequence of the area has been presented by Yli-Halla and Mokma (2001). A representative pedon on a soil surface that is about 90 $\mathrm{m}$ above the sea level in a slightly undulating field was selected for a more detailed study. Similar soil conditions have been verified in the area. The objective of this study was to determine the effect of anthropogenic activities on the pedogenesis of a clayey soil. The specific aim of the study was to investigate the evidence for clay translocation, conducive to the formation of argic (WRB) or argillic (Soil Taxonomy) horizons. While we are reporting anthropogenic influences on pedogenesis of only one pedon studied with great detail, this soil condition is not an isolated example but likely extensive in northern latitudes where artificial drainage has occurred in soils that have an aquic soil moisture regime.

\section{Materials and methods}

The sediments from which the referenced pedon has formed were deposited in the Yoldia Sea $(10,200-9,500$ YBP $)$. As a result of lowering of sea level and isostatic rebound, the sediments emerged from the sea about 8000 YBP (Rainio 1997). The clayey marine sediments are as thick as $30 \mathrm{~m}$ and are surrounded by glacial till in the upper parts of the landscape and even by exposed bedrock. The study area is drained by the River Loimijoki, a few meters below the surfaces of the fields. According to the old maps of the Jokioinen Manour, the field has been in agricultural use since the 17th century. The average annual soil temperature is about $6{ }^{\circ} \mathrm{C}$ (Heikinheimo and Fougstedt 1992) and the average annual precipitation for the period 1980-1999 is 644 $\mathrm{mm}$ and ranges between 530 and $740 \mathrm{~mm}$. The average runoff was $50 \%$ of annual precipitation (Turtola and Paajanen 1995). Spring and autumn cereals have been the dominant cropping systems.

The pedon was sampled by the genetic horizons. Particle size distribution was determined according to a pipette method after the soil was dispersed with hydrogen peroxide and hydrochloric acid (Elonen 1971). Total carbon (C) was determined with a Leco dry combustion apparatus and it was assumed that all C was in the organic form. Soil $\mathrm{pH}$ was measured in a water suspension using a soil to solution ratio of 1:2.5 after 18 hours of reaction time. Exchangeable $\mathrm{Ca}, \mathrm{Mg}, \mathrm{K}$ and $\mathrm{Na}$ were extracted with $1 \mathrm{M}$ ammonium acetate ( $\mathrm{pH} 7.00$, $5 \mathrm{~g}$ of soil, four successive $25-\mathrm{ml}$ portions of the extractant, 1 h equilibrium before each extraction) and titratable acidity was determined by titrating the extract back to $\mathrm{pH} 7.00$ using $0.02 \mathrm{M} \mathrm{NaOH}$. CEC was calculated as the sum of $\mathrm{Ca}, \mathrm{Mg}, \mathrm{K}, \mathrm{Na}$ and titratable acidity. These basic properties of the soil are presented in Table 1. Clay content of the pedon tends to increase with depth with a distinct increase between the Ap and Bw horizons and there is hardly any sand below the plough layer. Concentration of organic C, soil pH and CEC in different horizons of the investigated soil are typical of agricultural clay soils of Southern Finland (e.g. Sippola 1974, Yli-Halla and Mokma 2001, Peltovuori et al. 2003). Exchangeable Ca decreased with depth whereas exchangeable $\mathrm{K}, \mathrm{Mg}$ and $\mathrm{Na}$ increased. The cation composition (data not presented, see in detail Yli-Halla and Mokma 2001) reflects the marine origin of the sediment and the agricultural liming with calcite.

A profile description of the pit was made according to the Soil Survey Manual (Soil Survey Staff 1993) with colors determined using Munsell Soil Color Charts. Bulk density was determined as three replicates with the clod method of Brasher et al. (1966). The clods were sealed with saran resin and weighed air-dry and at 33kPa moisture tension in water and in air. Using these results, coefficients of linear extensibility (COLE) were calculated for each horizon (Grossman et al. 1968). The soil was classified according to the World Reference Base 


\section{AGRICULTURAL AND FOOD SCIENCE}

Vol. 18 (2009): 388-401.

Table 1. Some physical and chemical properties of the Jokioinen pedon. $\mathrm{OC}=$ organic carbon, $\mathrm{CEC}=$ cation exchange capacity at $\mathrm{pH} 7.00, \mathrm{BS}=100 \times(\mathrm{Ca}+\mathrm{Mg}+\mathrm{K}+\mathrm{Na}) / \mathrm{CEC}$. Clay, silt and sand stand for particle separates of $<0.002 \mathrm{~mm}$, $0.002-0.060 \mathrm{~mm}$ and $0.060-2 \mathrm{~mm}$, respectively.

\begin{tabular}{lccccccccc}
\hline Horizon & $\begin{array}{c}\text { Depth } \\
\mathrm{cm}\end{array}$ & $\begin{array}{c}\text { Clay } \\
\%\end{array}$ & $\begin{array}{c}\text { Silt } \\
\%\end{array}$ & $\begin{array}{c}\text { Sand } \\
\%\end{array}$ & $\begin{array}{c}\mathrm{OC} \\
\%\end{array}$ & $\mathrm{pH}$ & $\begin{array}{c}\mathrm{CEC} \\
\mathrm{cmol}_{\mathrm{c}} \mathrm{kg}^{-1}\end{array}$ & $\begin{array}{c}\text { CEC } \\
\mathrm{cmol}_{\mathrm{c}} \mathrm{kg}^{-1} \mathrm{clay}\end{array}$ & $\begin{array}{c}\mathrm{BS} \\
\%\end{array}$ \\
\hline Ap1 & $0-10$ & 41 & 45 & 14 & 2.19 & 6.20 & 24.9 & $(60.6)$ & 65 \\
Ap2 & $10-27$ & 40 & 46 & 14 & 2.28 & 6.33 & 24.9 & $(62.3)$ & 65 \\
Bt & $27-38$ & 61 & 35 & 4 & 0.35 & 7.08 & 29.5 & 48.2 & 87 \\
Btg & $38-72$ & 63 & 33 & 4 & 0.29 & 7.23 & 24.5 & 39.1 & 93 \\
BCtg1 & $72-112$ & 66 & 33 & 1 & 0.26 & 7.28 & 21.9 & 33.2 & 94 \\
BCtg2 & $112-140$ & 63 & 35 & 2 & 0.26 & 7.40 & 24.6 & 39.0 & 94 \\
Cg & $140-150+$ & 79 & 19 & 2 & 0.25 & 7.32 & 31.2 & 31.2 & 95 \\
\hline
\end{tabular}

for Soil Resources (WRB, FAO 2006) and U.S. Soil Taxonomy (Soil Survey Staff 1999).

Mineralogical composition of the sand $(0.05-2$ $\mathrm{mm})$, silt $(2-5 \mu \mathrm{m})$ and clay $(<2 \mu \mathrm{m})$ fractions was determined on a semi-quantitative basis by $\mathrm{X}$-ray diffraction using $\mathrm{Cu} \mathrm{K} \alpha$ radiation with a Philips $\mathrm{X}$-ray diffractometer. The clays were isolated using sedimentation. The clay suspension was flocculated with $0.5 \mathrm{M} \mathrm{MgC1}_{2}$. After washing the clays free of salts they were sedimented on ceramic-tile plates via suction. Pretreatments used for Mg-saturated clays were air dry, ethylene glycol, and $350^{\circ} \mathrm{C}$ and $550^{\circ} \mathrm{C}$ heat treatments. Heated samples were maintained at respective temperatures for at least 2 hours before analysis. Clays were scanned from $2^{\circ} 2 \theta$ to $32^{\circ} 2 \theta$ at a scan speed of $2^{\circ} 2 \theta \mathrm{min}^{-1}$. The sands and silts were ground for one minute in a disc mill grinder to reduce particle size to a fine powder. The powder was then loaded into aluminum box mounts for X-ray analysis and scanned from $2^{\circ} 2 \theta$ to $50^{\circ} 2 \theta$ at a scan speed of $2^{\circ} 2 \theta \mathrm{min}^{-1}$. Minerals were identified according to Brown and Brindley (1984).

Oriented samples for micromorphological examinations were collected from each horizon using $8 \times 16 \times 5 \mathrm{~cm}$ Kubiëna tins. Samples were impregnated under vacuum (Ashley 1973) using a polyester resin diluted 2:1 with acetone. Hardening of the resin was accomplished using $8 \times 10^{6} \mathrm{Rad}$ gamma radiation (Drees and Drees 1997). Vertically oriented soil thin sections $(40 \times 60 \mathrm{~mm})$ were prepared from each sample. Sample blocks were polished, mounted on glass slides with epoxy and ground to a final thickness of $30 \mu \mathrm{m}$ and described using the terminology of Bullock et al. (1985) and Stoops (2003).

The depth of groundwater was monitored weekly or biweekly during the period 1992-1995 and during 2001-2005 at distances of 50-200 m from the soil pit. The measurements were carried out primarily from April through August using bottom closed, perforated groundwater observation pipes (diameter $45 \mathrm{~mm}$ ) which extended to the depth of 80-150 cm. During the latter period, the pipes were deeper than during the earlier period. In 1992-1995, there were six pipes and in 2001-2005 eight pipes. According to Aura (1995), this method is suitable for monitoring the groundwater level of Finnish clay soils since a slight lowering of the water pressure head from zero clearly reduces the water content of clay soil above the groundwater surface and groundwater level can be determined accurately.

The depth of frost was measured in the investigated field area at two-week intervals in 10 winters between 1982-2005 as a colour change of methylene blue tubes (Soveri and Varjo 1977). These results consist of observations made in $3-8$ pipes annually. The concentration of methylene blue was

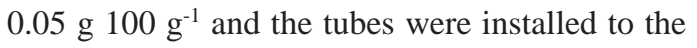
depth of $100 \mathrm{~cm}$.

Cracking of the soil was measured in four areas of the field during the dry summer of 2006 using a 


\section{AGRICULTURAL AND FOOD SCIENCE}

Yli-Halla, M. et al. Luvisols/Alfosols in Finland

simple crackometer, consisting of a flexible tape, made of 0.5-mm thick spring steel 1-m long. Metal plates were fixed at each end of the tape. One plate was 5 -mm wide by $2 \mathrm{~mm}$-thick while the other plate was 10 -mm-wide by 2-mm thick. The depth of 180 cracks which were more than $5 \mathrm{~mm}$ wide at the soil surface was measured by pushing the metal strip into the crack. The depth of penetration indicates how deep the crack was accessible to the crackometer. In large cracks the other end of the crackometer tape was inserted to determine the depth to which the cracks were at least $10 \mathrm{~mm}$ wide.

\section{Results and discussion}

\section{Soil morphology}

The Ap1 horizon had weak granular and subangular blocky structure (Table 2). This horizon contained many roots and worm burrows. Coarse prismatic, parting to angular blocky structure, was observed in the Ap2 horizon. The Ap1 and Ap2 had been tilled as one plough layer until 1999 when tillage was changed from conventional to conservation tillage. Hence, the prismatic structure in the Ap2 horizon had formed rapidly in this soil (descrip-

Table 2. Selected morphological properties of the Jokioinen pedon. Described and sampled on September 10, 1999 and July 3, 2001.

\begin{tabular}{|c|c|}
\hline Horizon & Description \\
\hline Ap $1,0-10 \mathrm{~cm}$ & $\begin{array}{l}10 \mathrm{YR} 4 / 2 \text { (dark grayish brown), } 10 \mathrm{YR} 7 / 3 \text { (very pale brown, dry); silty clay; weak coarse suban- } \\
\text { gular blocky and moderate fine-to-medium granular structure; firm, abrupt smooth boundary. }\end{array}$ \\
\hline Ap2, 10-27 cm & $\begin{array}{l}\text { 10YR 4/2 (dark grayish brown); silty clay; weak coarse-to-very coarse prismatic parting to coarse } \\
\text { angular blocky structure; firm; abrupt smooth boundary. }\end{array}$ \\
\hline Bt, $27-38 \mathrm{~cm}$ & $\begin{array}{l}10 \text { YR } 4 / 2 \text { (dark grayish brown); common medium faint } 10 \mathrm{YR} 4 / 3 \text { (brown) mottles within the } \\
\text { aggregates; common small faint } 10 \mathrm{YR} 2 / 2 \text { (very dark brown) Mn oxide nodules; clay; weak } \\
\text { very coarse prismatic parting to weak coarse-to-very coarse angular blocky structure; very } \\
\text { firm; clear smooth boundary. }\end{array}$ \\
\hline Btg $1,38-72 \mathrm{~cm}$ & $\begin{array}{l}\text { Matrix: } 10 \mathrm{YR} 4 / 2 \text { (dark grayish brown); Prism faces: } 2.5 \mathrm{Y} 4 / 1 \text { (dark gray); common medium } \\
\text { faint } 10 \mathrm{YR} 4 / 3 \text { (brown) mottles within the aggregates; common small faint } 10 \mathrm{YR} 2 / 2 \text { (very } \\
\text { dark brown) Mn oxide nodules; clay; weak medium-to-coarse prismatic parting to moderate } \\
\text { fine angular blocky structure; firm; clear smooth boundary. }\end{array}$ \\
\hline BCtg1, 71-112 cm & $\begin{array}{l}\text { Matrix: } 10 \mathrm{YR} 4 / 2 \text { (dark grayish brown); Prism faces: } 2.5 \mathrm{Y} 4 / 1 \text { (dark gray); common medium } \\
\text { faint } 10 \mathrm{YR} 4 / 3 \text { (brown) mottles within the aggregates; common small faint } 10 \mathrm{YR} 2 / 2 \text { (very } \\
\text { dark brown) Mn oxide nodules; clay; weak medium-to-coarse prismatic parting to moderate } \\
\text { fine angular blocky structure; firm; clear smooth boundary. }\end{array}$ \\
\hline BCtg2, 112-140 cm & $\begin{array}{l}\text { Matrix: } 10 \mathrm{YR} 4 / 2 \text { (dark grayish brown); Prism faces: } 2.5 \mathrm{Y} 4 / 1 \text { (dark gray); common medium } \\
\text { faint } 10 \mathrm{YR} 4 / 3 \text { (brown) mottles within the aggregates; common small faint } 10 \mathrm{YR} 2 / 2 \text { (very } \\
\text { dark brown) Mn oxide nodules; clay; moderate extremely coarse prismatic parting to mod- } \\
\text { erate coarse platy and further to strong medium-to coarse angular blocky structure; moder- } \\
\text { ate fine-to-medium wedge-shaped vertical unstriated prisms associated with desiccation joint } \\
\text { planes firm; clear smooth boundary. }\end{array}$ \\
\hline
\end{tabular}

$\mathrm{Cg}, 140-150 \mathrm{~cm}$

10YR 4/3 (brown, 80\%) strata of clay and 2.5Y 5/1 (gray, 20\%) strata of silt; weak-to-moderate medium platy parting to moderate fine angular blocky structure; firm. 


\section{AGRICULTURAL AND FOOD SCIENCE}

Vol. 18 (2009): 388-401.

tion in July, 2001) likely as a result of shrink-swell cycles caused by wetting and drying as well as by freezing and thawing. Prismatic structure that parted to angular blocky structure occurred in the horizons below the plough layer. The prisms in the BCtg horizons were coarser than those in the Btg horizon above. The BCtg2 horizon (112-140 cm) had common unstriated or grooved wedge-shaped prisms, associated with desiccation joint planes. The prisms terminated at acute angles and thus the term wedge-shaped prisms is appropriate. These prisms were vertical, not tilted as required for Vertisols (Soil Survey Staff 1999, FAO 2006). It is likely that this prismatic structure has been formed subsequent to drainage and shrinkage of the soil. Within the investigated depth, $150 \mathrm{~cm}$, massive material was not encountered; even the Cg horizon (140-150+ cm) contained some desiccation cracks.

No sedimentary bedding planes were observed in the Ap and Bt horizons (Fig. 1a). Natural shrinkswell and anthropogenic turbation had destroyed rock structure in the Ap and $\mathrm{Bt}$ horizons, down to $38 \mathrm{~cm}$. The sedimentary origin of the parent material was still visible below $38 \mathrm{~cm}$ in thin sections of the Btg horizon as weak bedding planes and in the BCtg1 horizon below $72 \mathrm{~cm}$ as thin silt strata (Table 2) observable even by the naked eye. In the two BCtg horizons $(72-140 \mathrm{~cm})$, the prisms broke horizontally into platy aggregates according to the primary sedimentation strata. In the BCtg2 horizon $(112-140 \mathrm{~cm})$ the bedding planes were so strongly expressed that nearly $50 \%$ of the rock structure remained in this horizon.

No clay films were observed on ped faces or along channels in any horizon by the naked eye in the field. However, investigation of thin sections revealed that clay translocation was a common feature in this soil. Some thick continuous clay coats were present along pores, even in the Ap horizons. In the Ap2 horizon there was direct evidence of the shrink-swell phenomenon as exhibited by stressoriented clay around skeleton grains and also in the matrix (granostriated and striated b-fabric). Illuvial clay was more abundant in the Bt (Fig. 1a, b) and Btg horizons (Fig. 1c) with occasional embedded illuvial clay (hypocoatings) and plugged pores. Peds in the Bt horizon commonly had very thin pressure faces (porostriated) and 45-90 $\mu \mathrm{m}$ layers of illuviated clay coatings (Figs. 1a, c). Maximum amounts of illuvial clay were present in the BCtg1 (Fig. 1d) and BCtg2 horizon (112-140 cm, Fig. 1f, $\mathrm{g}, \mathrm{h})$. In the the BCtg2 horizon, there were strong $(0.5 \mathrm{~mm})$ continuous bands of illuvial clay coats along channels and vughs, particularly along prism faces and previous root channels. This is interpreted as soil zones of lower shrink/swell activity and more stable structural surfaces on which translocated clay could be deposited without subsequent pedoturbation disturbance. The original platy structure was most obvious in the Cg horizon (Fig. 1i) as alternating lighter and darker colors created by the sedimentation of different materials, but even in this horizon, it is apparent that well developed illuvial laminar clay coatings occur partly filling previous root channels (Fig. 1j). The depth at which translocated clay was best preserved further corroborates the evidence that the BCtg horizons undergo less physical disturbance due to freeze/thaw, shrink/swell and other pedoturbation activities.

In our monitoring, the maximum depth of the frost occurred usually between late February and early April and ranged from $47 \mathrm{~cm}$ to $96 \mathrm{~cm}$, with a mean of $67 \mathrm{~cm}$ (Fig. 2). The period in which the soil was frozen to the depth of at least $40 \mathrm{~cm}$ (Ap and $\mathrm{Bt}$ horizons) ranged annually from 1.5 months to 6 months, with a mean of 3.5 months. The annual average depth of frost closely corresponds to the lower boundary of the Btg horizon $(72 \mathrm{~cm})$. According to Heikinheimo and Fougstedt (1992), monitoring soil temperature at the depths of 20,50, 100 and $300 \mathrm{~cm}$ at 5-day intervals in 1971-1990 in a clay soil of Jokioinen, there is only $1 \%$ probability for freezing mean monthly soil temperatures at the depth of $100 \mathrm{~cm}$ in winter (February, March, April). These results indicate that the BCtg1 horizon seldom and the BCtg2 and Cg horizons practically never freeze, partly explaining the rock structure in these horizons.

Bulk density (BD) was lowest in the Ap1 horizon, attributable to recent tillage (Table 3). The Ap2, which has about the same amount of organic matter as Ap1, and particularly the Bt horizon, were secondarily compacted by tillage, and exhibited relatively high bulk densities with few pores and 


\title{
AGRICULTURAL AND FOOD SCIENCE
}

\author{
Yli-Halla, M. et al. Luvisols/Alfosols in Finland
}
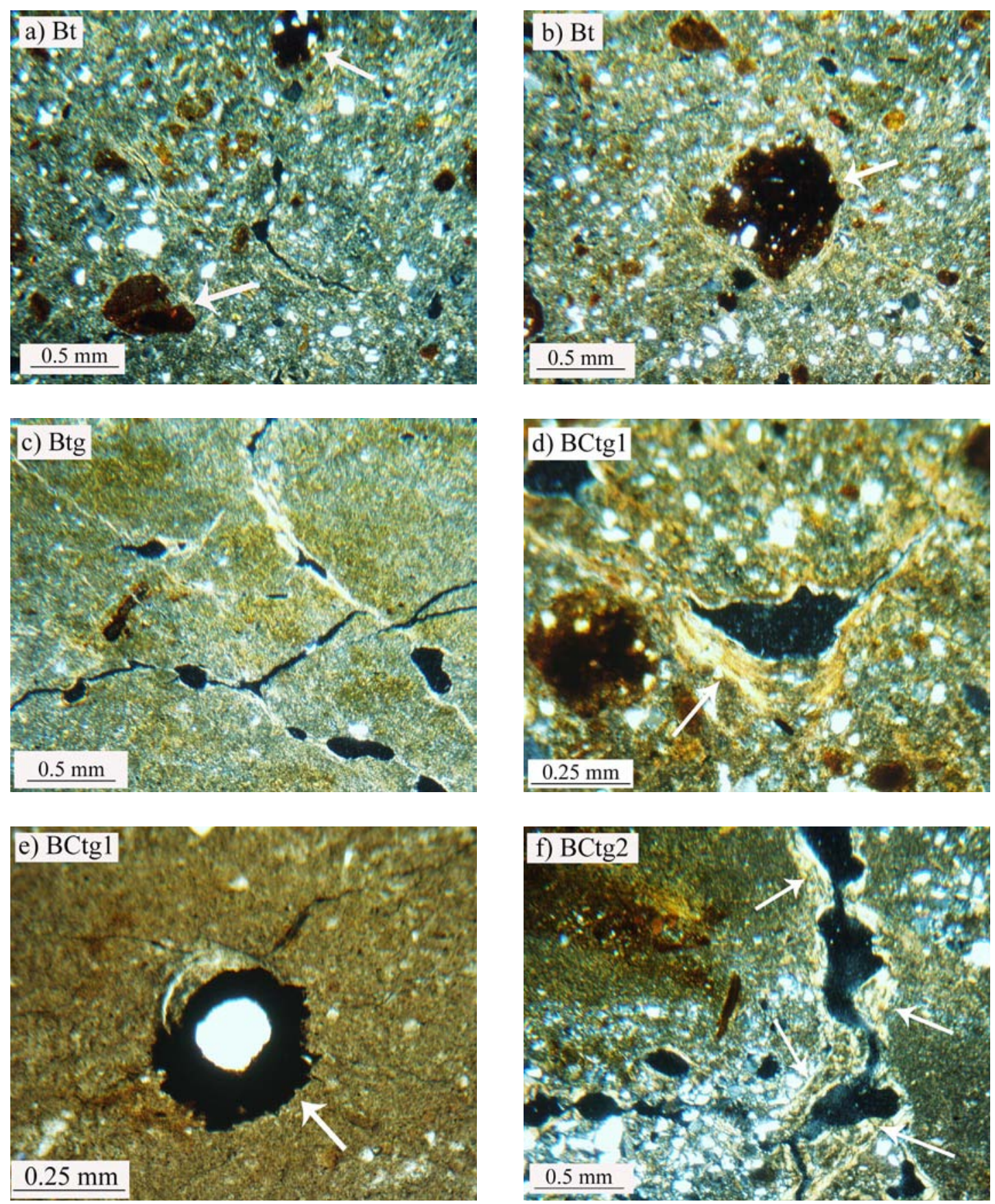


\section{AGRICULTURAL AND FOOD SCIENCE}

Vol. 18 (2009): 388-401.
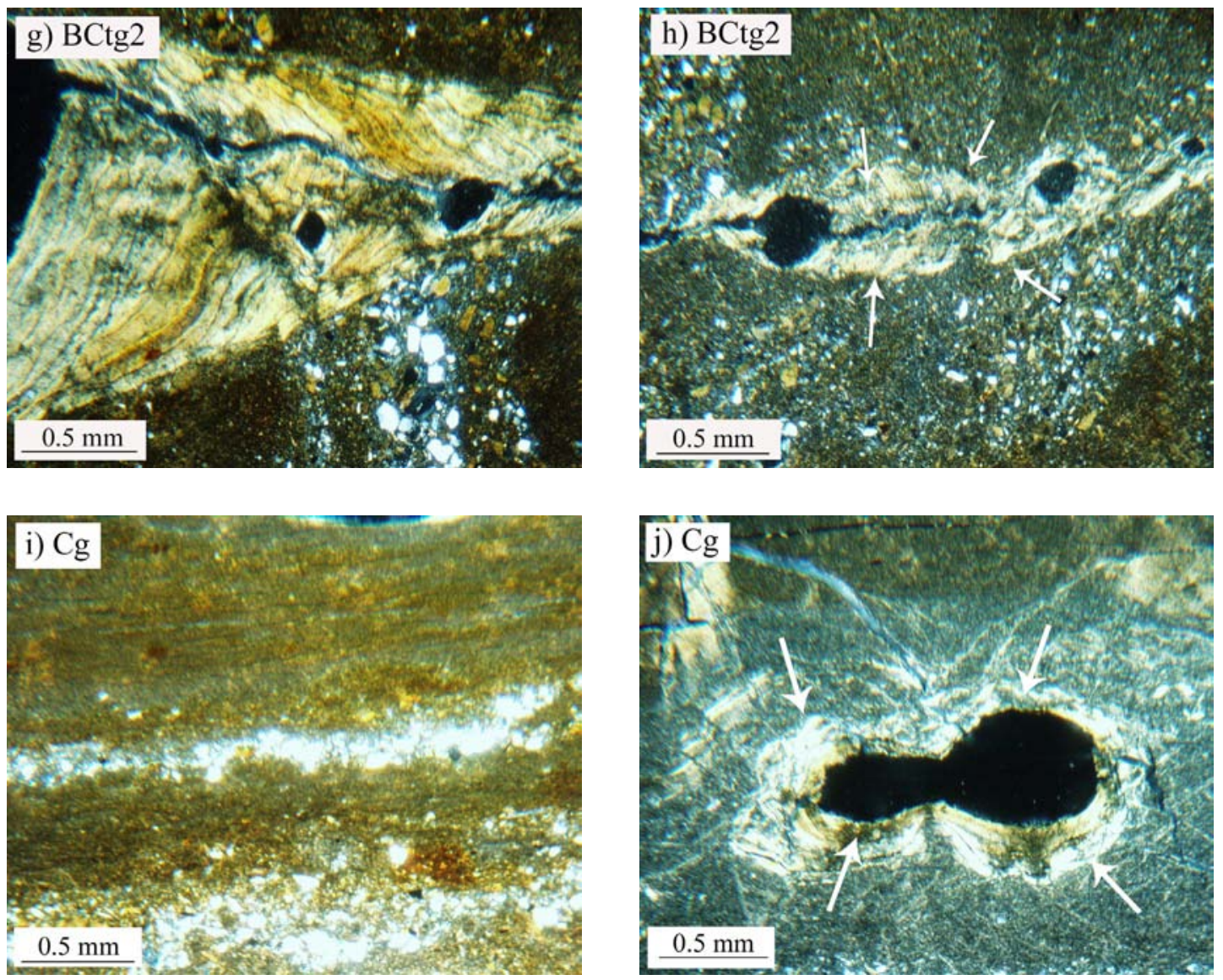

Fig. 1. Selected micromorphological features from different horizons of the Jokioinen pedon. All micrographs taken in cross polarized light mode except (e) in plane polarized light mode. (a) Bt horizon $(27-38 \mathrm{~cm})$ with weak pedality, double porphyric groundmass, dense clayey micromass, striated b-fabric, porostriated, and many orthic Fe-Mn nodules (arrow) with sharp boundaries without stress oriented coatings; (b) Bt horizon $(27-38 \mathrm{~cm}$ ) with weak pedality, double porphyric groundmass, striated b-fabric, and an orthic Fe-Mn nodule (arrow) with stress-oriented (granostriated) coating; (c) Btg horizon $(38-72 \mathrm{~cm})$ with dense clayey micromass, striated b-fabric, and many illuvial clay coatings along channels and chambers; (d) BCtg1 horizon $(72-112 \mathrm{~cm}$ ) with single and double porphyric groundmass, speckled b-fabric, and laminar illuviated clay coatings (arrow) along a chamber; (e) BCtg1 horizon $(72-112 \mathrm{~cm}$ ) with weak pedality, dense clayey micromass, Fe-Mn pipestem concretion (arrow) with sharp boundary and without stress - oriented clay coats; (f) BCtg2 horizon (112-140 cm) with single and double porphyric groundmass, dense clayey micromass, speckled b-fabric, and strong continuous illuviated clay coatings (arrow) along prism faces; (g) BCtg2 horizon (112-140 cm) dense clayey micromass, speckled b-fabric, with strong continuous laminar illuviated clay coating (yellow colour) along a planar void; (h) BCtg2 horizon (112-140 cm) with single and double porphyric groundmass, dense clayey micromass, speckled bfabric, and strong continuous illuviated clay coatings (arrows) along channels and chambers; (i) Cg horizon (140-150+ $\mathrm{cm}$ ) with banded clayey micromass and strial b-fabric representing rock structure, and (j) $\mathrm{Cg}$ horizon $(140-150+\mathrm{cm})$ with laminar illuviated clay coating (arrow) along a vugh. 


\section{AGRICULTURAL AND FOOD SCIENCE}

Yli-Halla, M. et al. Luvisols/Alfosols in Finland

Table 3. Moist (33 kPa) and dry bulk densities and the coefficient of linear extensibility (COLE) of different horizons of the Jokioinen soil ( $\mathrm{s}=$ standard deviation).

\begin{tabular}{|c|c|c|c|c|c|c|c|}
\hline \multirow[t]{2}{*}{ Horizon } & \multirow[t]{2}{*}{$\begin{array}{l}\text { Depth } \\
\text { cm }\end{array}$} & \multicolumn{2}{|c|}{$\begin{array}{c}\text { Moist bulk } \\
\text { density, kg dm-3 }\end{array}$} & \multicolumn{2}{|c|}{$\begin{array}{c}\text { Dry bulk } \\
\text { density, kg dm-3 }\end{array}$} & \multicolumn{2}{|c|}{$\begin{array}{l}\text { COLE } \\
\mathrm{cm} \mathrm{cm}^{-1}\end{array}$} \\
\hline & & Mean & $\mathrm{s}$ & Mean & $\mathrm{s}$ & Mean & $\mathrm{s}$ \\
\hline Ap1 & $0-10$ & 1.05 & 0.02 & 1.26 & 0.08 & 0.06 & 0.024 \\
\hline Аp2 & $10-27$ & 1.46 & 0.01 & 1.59 & 0.02 & 0.03 & 0.002 \\
\hline $\mathrm{Bt}$ & $27-38$ & 1.42 & 0.05 & 1.71 & 0.02 & 0.07 & 0.015 \\
\hline Btg & $38-72$ & 1.30 & 0.02 & 1.60 & 0.03 & 0.07 & 0.006 \\
\hline BCtg1 & $72-112$ & 1.32 & 0.02 & 1.53 & 0.03 & 0.05 & 0.002 \\
\hline BCtg2 & $112-140$ & 1.33 & 0.01 & 1.53 & 0.05 & 0.05 & 0.008 \\
\hline $\mathrm{Cg}$ & $140-150$ & 1.19 & 0.10 & 1.45 & 0.04 & 0.07 & 0.020 \\
\hline
\end{tabular}

roots. Deeper in the subsoil, BD decreased slightly below the $\mathrm{Bt}$ horizon because soil compaction by machinery is less marked in the deeper horizons. On the other hand, this trend in BD suggests that the soil may not have reached the same state of ripeness as surface horizons because clay domains still retained much of the open architecture, likely the result of less intensive drying. This result is in line with the rather weak prismatic structure in the $\mathrm{BC}$ and $\mathrm{C}$ horizons.

The matrix color of the horizons was predominantly grey with many yellowish brown and reddish brown unconsolidated redox concentrations of Fe-Mn oxyhydroxide precipitates (Table 2). Even the Ap1 and Ap2 horizons contained many 0.25-0.5 mm (few up to $4 \mathrm{~mm}$ diameter) Fe-Mn nodules with abrupt or diffuse boundaries, most of which had many silt-sized skeleton grains of quartz. The coarse particles likely originated as a result of wave action from the surrounding areas of glacial till (islands in the former sea), the closest area of which is only about $100 \mathrm{~m}$ from the investigated pedon. In the Ap, Bt and Btg horizons, Fe-Mn nodules with sharp boundaries were found with striated clay surrounding them (granostriated) indicating relic nodule formation and active shrink swell conditions (Fig. 1b). Oriented clay around the nodules retards diffusion of $\mathrm{Fe}$ and $\mathrm{Mn}$ into and out of the nodules. The nodules were likely formed in situ before the soil was artificially drained. In other cases the Fe-Mn nodules had gradual boundaries without stress oriented coatings, especially in the Btg, BCtg and Cg horizons suggesting their active formation (Figs. 1b, 1c).The nodules were fewer and smaller in diameter in the Bt horizon but more common and larger in the Btg, BCtg, and $\mathrm{Cg}$ horizons. Those in the BCtg and $\mathrm{Cg}$ horizons did not have stress clay coatings (Fig. 1c) indicating they remain active. Many Fe-Mn pipestems (0.5 $\mathrm{mm}$ in diameter) occurred in the Btg, BCtg and $\mathrm{Cg}$ horizons surrounding previous root channels (Fig. 1e). The presence of these redoximorphic features indicates this pedon was saturated with water for long periods of time during most years even after the sea level dropped below the elevation of the pedon. These features remain after artificial drainage. Some redox concentrations at least in the subsurface horizons likely formed after the installation of the drainage. The prism faces had no mottling, which occurred only in the interiors of the peds. The prism faces also had a slightly lower chroma than the interiors. This color pattern suggests occasional episaturation. Since the surfaces of peds did not have a higher color value than the matrix, the criteria of a stagnic color pattern (FAO 2006) were not fully met. 
Vol. 18 (2009): 388-401.

\section{Groundwater depths, soil extensibility and crack formation}

Soil cracking is a function of the cracking potential, and drying of the soil. Our monitoring of the groundwater level indicates that in many years there is a chance for desiccation of the BCtg horizons and the upper part of the $\mathrm{Cg}$ horizon at least to the depth of $150 \mathrm{~cm}$ in this subsurface drained field. A representative example of the depth of groundwater is shown in Fig. 2. In each of the nine years studied, the water level was measurable from May to early July, usually fluctuating between $60 \mathrm{~cm}$ and $100 \mathrm{~cm}$. The average depth of groundwater was $79 \mathrm{~cm}, 85$ $\mathrm{cm}$ and $86 \mathrm{~cm}$ in May, June and July, respectively. In five out of the nine years, the groundwater level in August fluctuated between $40 \mathrm{~cm}$ and $110 \mathrm{~cm}$, with a mean at $70 \mathrm{~cm}$, so that in these years even the BCtg horizons were saturated nearly the whole summer. In turn, in four years, the groundwater level was below the measurement pipes throughout August, and in some years, for instance in 2002, the dry period extended into September-October. There was positive identification of the water level being deeper than $110 \mathrm{~cm}$ for at least two months in 1992,

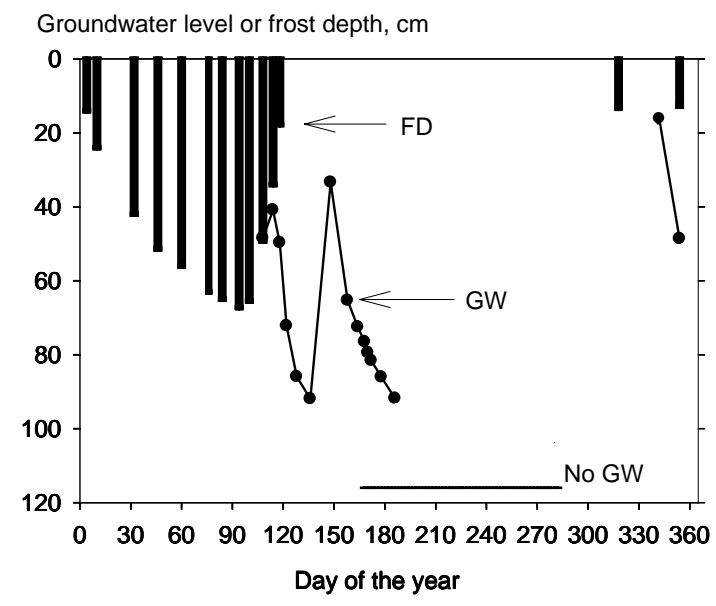

Fig. 2. Groundwater level (GW) and frost depth (FD) in 2006. The horizontal line indicates the period when growndwater level was in most (some) observation points deeper than the determination depth.
1993, 1994, 2002 and 2005. Moreover, our records indicate that of the 10 soil profiles investigated from 1997-2004, five had groundwater above 150 $\mathrm{cm}$ and five had no groundwater within $150 \mathrm{~cm}$ of soil surface during the few days a pit was open. The groundwater was at the depth of $140 \mathrm{~cm}$ at the time of sampling on July 3, 2001.

Coefficient of linear extensibility (COLE) of the pedon averaged $0.06 \mathrm{~cm} \mathrm{~cm}^{-1}$, ranging from 0.03 to $0.07 \mathrm{~cm} \mathrm{~cm}^{-1}$ (Table 1). This COLE value is in line with the micaceous - vermiculitic clay mineralogy, with no smectite observed (Table 4). Moreover, in spite of the high clay content, less than half of the clay fraction in the subsoil of Finnish clay soils consists of fine clay $(<0.2 \mathrm{um}$ ), and the coarse clay fraction contains much quartz and feldspars (Sippola 1974) that is not conducive to shrink-swell phenomenon. The COLE values of Vertisols are usually in the range of $0.1-0.2 \mathrm{~cm} \mathrm{~cm}^{-1}$, the present soil marginally meeting the criterion of the vertic attribute of Soil Taxonomy and the WRB system $\left(\mathrm{COLE}>0.06 \mathrm{~cm} \mathrm{~cm}^{-1}\right)$. In spite of the cracking potential indicated by the COLE values, the actual cracking in the $\mathrm{B}, \mathrm{BC}$ and $\mathrm{C}$ horizons appeared to be only modest. The cracks that were more than 5 $\mathrm{mm}$ wide at the soil surface had depths between 7 and $85 \mathrm{~cm}$, with a median of only $17 \mathrm{~cm}$. Of the 180 cracks checked only 11 were more than $10 \mathrm{~mm}$ wide (maximum $18 \mathrm{~mm}$ ) at the soil surface, and none of the cracks were wider than $10 \mathrm{~mm}$ below the Ap horizons.

\section{Pedogenesis and classification}

The major pedogenic processes currently active in the Jokioinen soil are shrink-swell pedoturbation, formation of Fe-Mn nodules and pipestems, structure formation and, most significantly, clay translocation. Desiccation of the parent material sediments began after the surface emerged from water as a result of isostatic rebound and lowering of the sea level, and was enhanced when plants began to grow. Crack formation and root channels of wetland plants, such as reeds, increased aeration. As a result, $\mathrm{Fe}$ and $\mathrm{Mn}$ began to oxidize forming 


\section{AGRICULTURAL AND FOOD SCIENCE}

Yli-Halla, M. et al. Luvisols/Alfosols in Finland

Table 4. Semiquantitative mineralogical composition $(+=$ least abundant, $++=$ moderately abundant, $+++=$ most abundant) of sand, silt and clay fractions of selected horizons.

\begin{tabular}{|c|c|c|c|c|c|c|c|}
\hline Horizon & Quartz & Feldspar & Amphibole and pyroxene & Chlorite & Mica & Vermiculite & Vermiculite-mica \\
\hline & \multicolumn{7}{|c|}{ Sand } \\
\hline $\mathrm{Bw}$ & +++ & ++ & + & & & & \\
\hline \multirow[t]{2}{*}{ Cg } & +++ & ++ & + & & & & \\
\hline & \multicolumn{7}{|c|}{ Silt } \\
\hline $\mathrm{Bw}$ & +++ & +++ & + & + & & & \\
\hline \multirow[t]{2}{*}{ Cg } & +++ & ++ & + & + & + & & \\
\hline & \multicolumn{7}{|c|}{ Clay } \\
\hline $\mathrm{Bw}$ & ++ & + & + & + & ++ & ++ & ++ \\
\hline BCg1 & ++ & + & + & + & ++ & ++ & + \\
\hline Cg & ++ & + & + & + & ++ & ++ & \\
\hline
\end{tabular}

nodules and pipestem concretions in a gray matrix of the surface horizons. Improved drainage with ditches and addition of manure increased plant growth and consequently evapotranspiration. Installation of the 100-120 cm deep tile drainage, addition of chemical fertilizers, and use of improved varieties with deeper root systems further enhanced plant growth. For example, in the 18th and 19th centuries, the yields of winter rye and spring barley in Western Finland were between 700 and $1100 \mathrm{~kg} \mathrm{ha}^{-1}$ (Soininen 1974) while presently in the Jokioinen area they are around $4000 \mathrm{~kg} \mathrm{ha}^{-1}$. Increased bioactivity promoted transpiration, desiccation and aeration to greater depths. The soil has become drier than ever before. Formation of Fe and Mn precipitate continues in the lower horizons.

Desiccation cracks and the installation of subsurface tile have provided an effective route for removal of excess water from the solum, facilitating clay translocation. Clay translocation begins when dry clay is rewetted. Artificial drainage permits the soil to dry to a greater degree than before drainage. Tillage, especially conventional tillage, reduces the amount of aggregate organic matter cements (Six et al. 1998, 2000) and promotes disruption of aggregates, making the peds less stable and more susceptible to disruption of the fabric.
Contrary to drier climates, large amounts of drainage flow transport much of the eluvial clay out of the soil profile with drainage waters, decreasing the accumulation of illuvial clay in the subsoil. However, the subsoil seems to dry out sufficiently to allow part of the clay leaving the upper horizons to be attached to the surfaces of stable peds, probably to a greater extent during slow or limited drainage flow. The deeper soil horizons, which don't freeze or dry out, experience little pedoturbation, and even though high in clay, those horizons still maintain much of their rock structure. Illuvial clay continues to accumulate on the faces of peds and fill biopores. However, the Ap and $\mathrm{Bt}$ horizons experience more intensive pedoturbation (bioactivity, freeze/thaw and shrinking and swelling processes), and hence disrupt formation of clay coatings. As a result, few clay coatings persist, and those that were previously formed have become embedded into the ground mass.

We conclude that the maxima of illuvial clay in the Btg (38-72 cm) and BCtg2 $(112-140 \mathrm{~cm})$ horizons, correspond to the effective drainage depths during ditch drainage (until 1930's) and subsurface pipe drainage (the last 70 years), respectively. It is unlikely that clay illuviated into these horizons when they were saturated. It was shown in Michigan, USA that illuvial clay decreased with increas- 


\section{AGRICULTURAL AND FOOD SCIENCE}

Vol. 18 (2009): 388-401.

ing duration of saturation (Cremeens and Mokma 1986). In the current investigation, thin sections of Btg and BCtg2 horizons showed that both had more than 1 percent oriented clay. Because the plough layer overlies the Bt horizon, the 1 percent oriented clay meets the criteria of an argic/argillic horizon (Soil Survey Staff 1999, FAO 2006). The illuvial horizons have about 1.5 times as much clay as the Ap horizon, however, in these sedimentary soils it is probable that there is a lithologic discontinuity between the Ap and Bt horizon based on silt/sand ratios (Table 1 ). Thus, such clay ratios of eluvial to illuvial horizons need to be interpreted with caution. Because anthropogenic processes caused the eluviation and illuviation of clay, the Ap horizon is the eluvial zone.

Usually it is considered that development of an argic/argillic horizon is a relatively slow process (Buol et al. 1997, Breemen and Buurman 2002), taking at least a few thousand years. In southeastern Norway, loamy marine sediments under forest vegetation had developed into Luvisols in less than 2000 years (Schülli-Maurer et al. 2007). According to Alexandrovskiy (2007), diagnostic characteristics of a Luvisol may be reached in 300-700 years and a mature profile in 3000 years in a gray forest soil of Russia. However, clay illuviation has been demonstrated to have taken place in less than 200 years in deposits exposed from glaciers (Breemen and Buurman 2002). Alexandrovskiy (2007) also pointed out that the rates of pedogenesis in humid, temperate climates are much higher than those in arid regions. Recently Presley et al. (2004) demonstrated that irrigation of some 30 years in the semiarid climate of Kansas had increased clay illuviation substantially as compared to an unirrigated soil. The present results suggest that 70 years of improved agricultural drainage and farming practices, including annual tillage, is sufficient time to give rise to an argic (FAO 2006) or an argillic (Soil Survey Staff 1999) horizon. Structure formation seems to be a somewhat slower process, as indicated by the BCtg2 horizon with a rock structure having developed into an argic/argillic horizon.

A comparison can be made between the amount of illuvial clay needed for a diagnostic argic/argillic horizon and the quantities of suspended mate- rial in drainage waters in clay soils of Finland. In a $15-\mathrm{cm}$ thick horizon with a BD of $1.5 \mathrm{~kg} \mathrm{dm}^{-3}$, $1 \%$ of illuvial clay translates into about $23,000 \mathrm{~kg}$ ha $^{-1}$. In the study of Turtola and Paajanen (1995) and Uusitalo et al. (2001) suspended material in the drainage flow leaving the solum in a clay soil of Jokioinen amounted annually to about $1000 \mathrm{~kg}$ $\mathrm{ha}^{-1}$. If an arbitrary amount of $500 \mathrm{~kg} \mathrm{ha}^{-1}$ (i.e. one third of the material leaving the eluvial horizon) had been adhered to a $15 \mathrm{~cm}$-thick illuvial horizon each year, an argic/argillic horizon would be formed in 46 years. Koskiaho et al. (2002) studied the suspended soil in drainage water at another location in southern Finland. Using the same ratio of eluvial material remaining and leaving the solum in their study, it would require an estimate of 200 years for the formation of an argic/argillic horizon. This simple calculation suggests that a time estimate of 70 years would not be unrealistic for the formation of an argic/argillic horizon in a tilled and artificial drained clay soil of Finland.

If the agricultural activities were stopped and drainage discontinued, the aquic soil moisture regime natively prevailing in this soil will revert. However, it is likely that the argic/argillic horizon is an irreversible soil characteristic and it must therefore be taken into account in soil classification. Other diagnostic characteristics of the Jokioinen soil, relevant to classification, included an ochric epipedon, a CEC of $31.2-48.2 \mathrm{cmol}_{\mathrm{c}} \mathrm{kg}^{-1}$ clay ( $>24 \mathrm{cmol}_{\mathrm{C}} \mathrm{kg}^{-1}$ ) in the $\mathrm{B}, \mathrm{BC}$ and $\mathrm{C}$ horizons, a BS $>50 \%$ throughout the solum (Table 1), and the average COLE of 0.06 (Table 3). On this basis, we classified the pedon, according to the WRB system, as a Vertic Luvisol (Oxyaquic), or, according to Soil Taxonomy, a Typic Cryaqualf. The subgroup Typic Cryaqualfs is a provisional taxon in Soil Taxonomy, but a subgroup name Vertic Cryaqualfs would be justified by the soil characteristics. This is the first time that a Luvisol (WRB) or a Cryaqualf (Soil Taxonomy) is documented in a clay soil within the boreal area affected by the Weichselian glaciation.

This study suggests that agricultural activities impact boreal clay soils much below the plough layer in a manner which probably is partly irreversible. Drainage-induced desiccation creates struc- 


\title{
AGRICULTURAL AND FOOD SCIENCE
}

\author{
Yli-Halla, M. et al. Luvisols/Alfosols in Finland
}

ture and channels for transport of substances such as clay particles, and tillage promotes detachment of these particles. Firm evidence confirming the anthropogenic nature of the argic/argillic horizon is, however, difficult to obtain, since in the studied area, like everywhere in Finland, nearly all clay soils have been reclaimed for agriculture and have been drained with subsurface tile. Therefore, clay soils in an undrained state rarely exist to facilitate investigation of the extent of clay illuviation with and without anthropogenic influences.

Acknowledgement. The authors thank Ms. Marja-Liisa Westerlund for collecting the frost and grounwater data, Dr. Tapio Salo for preparing the Figure 2 and the staff of the MTT soil laboratory for carrying out many soil analyses for this study.

\section{References}

Alexandrovskiy, A.L. 2007. Rates of soil-forming processes in three main models of pedogenesis. Revista Mexicana de Ciencias Geologicas 24: 283-292.

Ashley, G.H. 1973. Impregnation of fine-grained sediments with a polyester resin: a modification of Altmuller's method. Journal of Sedimentary Petrology 43: 298-301.

Aura, E. 1995. Finite element modelling of subsurface drainage in Finnish heavy clay soils. Agricultural Water Management 28: 35-47.

Bullock, P., Federoff, N., Jongerius, A., Stoops, G. \& Tursina, T. 1985. Handbook for soil thin section description. Waine Research Publications. Wolverhampton, UK. 152 p.

Buol, S.W., Hole, F.D., McCracken, R.J. \& Southard, R.J. 1997. Soil genesis and classification. 4th ed. lowa State University Press., Ames, IA, USA. 527 p.

Brasher, B.R., Franzmeier, D.P., Valassis, V.T. \& Davidson, S.E. 1966. Use of saran resin to coat natural soil clods for bulk density and water retention measurements. Soil Science 101: 108.

Breemen, N. van \& Buurman, P. 2002. Soil formation. 2nd. ed. Kluwer Academic Publishers, Dordrecht, The Netherlands. $404 \mathrm{p}$

Brown, G. \& Brindley, G.W. 1984. X-ray diffraction procedures for clay mineral identification. In: Brindley, G.W. and G. Brown (eds). Crystal structures of clay minerals and their identification. Mineralogical Society Monograph, vol. 5. Spottiswoods Ballantyne, Colchester. p. 305-359.

Cremeens, D.L. \& Mokma, D.L. 1986. Argillic horizon expression and classification in soils of two Michigan hydrosequences. Soil Science Society of America Journal 50: 1002-1007.
Drees, L.R. \& Drees, L.D. 1997. Nuclear reactor irradiation to polymerize resin impregnated samples. Agronomy Abstracts 89: 308.

Elonen, P. 1967. Sprinkler irrigation on clay soils in southern Finland. Journal of the Scientific Agricultural Society of Finland 39: 65-77.

Elonen, P. 1971. Particle size analysis of soil. Acta Agralia Fennica 122: 1-122.

FAO 2006. World Reference Base for Soil Resources 2006. A framework for international classification, correlation and communication. World Soil Resources Reports 103. Rome, Italy. 128 p.

Grossman, R.B., Brasher, B.R., Franzmeier, D.P. \& Walker, J.L. 1968. Linear extensibility as calculated from natural-clod bulk density measurements. Soil Science Society of America Proceedings 32: 570-573.

Heikinheimo, M. \& Fougstedt, B. 1992. Statistic of soil temperature in Finland 1971-1990. Meteorological Publications 22. $75 \mathrm{p}$.

Kirchmann, H. 1991. Properties and classification of soils of the Swedish long-term fertility experiments. I. Sites at Fors and Kungsängen. Acta Agriculturae Scandinavica 41: 227-242.

Kirchmann, H. \& Eriksson, J. 1993. Properties and classification of soils of the Swedish long-term fertility experiments. I. Sites at Örja and Orup. Acta Agriculturae Scandinavica 43: 193-205.

Koskiaho, J., Kivisaari, S., Vermeulen, S., Kauppila, R., Kallio, K. \& Puustinen, M. 2002. Reduced tillage: Influence on erosion and nutrients lossess in a clayey field in southern Finland. Agricultural and Food Science in Finland 11: 37-50.

Mokma, D.L., Yli-Halla, M. \& Hartikainen, H. 2000. Soils in a young landscape on the coast of southern Finland. Agricultural and Food Science in Finland 9: 291-302.

Nyborg, Å.A. \& Solbakken, E. 2008. Norsk referansesystem for jordsmonn. Feltguide - jordmonnskartlegging. Håndbok fra Skog og landskap 04/08. Ås, Norge. $232 \mathrm{p}$.

Nyborg, Å., Solbakken, E., Svendgård-Stokke, S., Lågbu, R., Klagegg, O. \& Sperstad, R. 2008. Jordsmonnatlas for $\varnothing$ stfold. Atlas from Norwegian Forest and Lanscape Institute 01/08. 207 p.

Peltovuori, T., Uusitalo, R. \& Kauppila, T. 2002. Phosphorus reserves and apparent phosphorus saturation in four weakly developed cultivated pedons. Geoderma 110: 35-47.

Presley, D.R., Ransom, M.D., Kluitenberg, G.J. \& Finnell, P.R. 2004. Effect of thirty years of irrigation on the genesis and morpholology of two semiarid soils in Kansas. Soil Science Society of America Journal 68: 1916-1926.

Rainio, H. 1997. Kivennäismaalajit. Maaperäkartan 211304 selitys. (Mineral soils. Legend to the map of quaternary deposits, sheet 211304). Maanmittauslaitos - National Land Survey of Finland. $1 \mathrm{p}$.

Reintam, E. \& Köster, T. 2006. The role of chemical indicators to correlate some Estonian soils with WRB and Soil Taxonomy criteria. Geoderma 136: 199-209.

Schülli-Maurer, I., Sauer, D., Stahr, K., Sperstad, R. \& Sørensen, R. 2007. Soil formation in marine sediments and beach deposits of southern Norway: investigations of soil chronosequences in the Oslofjord region. Revista 


\title{
AGRICULTURAL AND FOOD SCIENCE
}

Vol. 18 (2009): 388-401.

Mexicana de Ciencias Geologicas 24: 237-246.

Sippola, J. 1974. Mineral composition and its relation to texture and to some chemical properties in Finnish subsoils. Annales Agriculturae Fenniae 13: 169-234.

Six, J., Paustian, K. Elliot, E.T. \& Combrink, C. 2000. Soil structure and organic matter: I. distribution of aggregatesize classes and aggregate-associated carbon. Soil Science Society of America Journal 64: 681-689.

Six, J., Paustian, K. Elliot, E.T. \& Doran, J.W. 1998. Aggregation and soil organic matter accumulation in cultivated and native grassland soils. Soil Science Society of America Journal 62: 1367-1377.

Soil Survey Staff 1993. Soil Survey Manual. U.S. Department of Agriculture Handbook No. 18. U.S. Government Printing Office, Washington, DC. 437 p.

Soil Survey Staff 1999. Soil Taxonomy. A basic system of soil classification for making and linterpreting soil surveys. 2nd Ed. Agriculture Handbook 436. U.S. Government Printing Office, Washington, DC. 869 p.

Soininen, A. 1974. Vanha maataloutemme. Maatalous ja maatalousväestö Suomessa perinnäisen maatalouden loppukaudella 1720-luvulta 1870-luvulle. Summary: Old traditional agriculture in Finland in the 18th and 19th centuries. Journal of the Scientific Agricultural Society of Finland 46 (Supplement). 459 p.

Soveri, J. \& Varjo, M. 1977. Roudan muodostumisesta ja esiintymisestä Suomessa vuosina 1955-1975. English summary: On the formation and occurrence of frost in Finland 1955-1975. Publications of the Water and Environmental Research Institute $20.66 \mathrm{p}$.

Stoops, G. 2003. Guidelines for analysis and description of soil and regolith thin sections. Soil Science Society of America, Madison, WI.184 p.

Turtola, E. \& Paajanen, A. 1995. Influence of improved subsurface drainage on phosphorus losses and nitrogen leaching from a heavy clay soil. Agricultural Water Management 28: 295-310.

Uusitalo, R., Turtola, E., Kauppila, T. \& Lilja, T. 2001. Particulate phosphorus and sediment in surface runoff and drainflow from clayey soils. Journal of Environmental Quality 30: 589-595.

Yli-Halla, M. \& Mokma, D.L. 1998. Soil temperature regimes in Finland. Agricultural and Food Science in Finland 7: 507-512.

Yli-Halla, M. \& Mokma, D.L. 2001. Soils in an agricultural landscape of Jokioinen, south-western Finland. Agricultural and Food Science in Finland 10: 33-43.

\section{SELOSTUS}

\section{Maankuivatus vaikuttaa savimaan maannostumiseen}

\author{
Markku Yli-Halla, Delbert L. Mokma, Laura Alakukku, Richard Drees ja Larry P. Wilding \\ MTT, Helsingin yliopisto, Michigan State University, USA ja Texas A\&M University, USA
}

Kuivatus muuttaa maan ominaisuuksia monin tavoin. Savisedimentin kuivuminen saa aikaan kutistumista ja rakenteen muodostumista. Rakenteellisen kutistumisen seurauksena syntyvät makrohuokoset toimivat ilman ja veden sekä siihen liuenneiden ja suspendoituneiden aineiden kulkureitteinä. Suomen ilmasto-oloissa kuivatus vaikuttaakin merkittävällä tavalla viljelymaiden pedogeneesiin. Maankuivatuksen vaikutuksia Jokioisilla sijaitsevan savimaan ominaisuuksiin tutkittiin tarkastelemalla maan makro- ja mikromorfologiaa horisonteittain 150 cm:n syvyyteen saakka. Peltoa on viljelty 1700 -luvulta lähtien, ja se on salaojitettu 1930-luvulla. Tilavuuspainon määritystä varten maakokkareet tasapainotettiin vakiokosteuteen ylipainemenetelmällä (33 $\mathrm{kPa})$. Kutistumiskerroin (Coefficient of Linear Extensibility, COLE) laskettiin kosteiden ja kuivien $\left(105^{\circ} \mathrm{C}\right)$ maakokkareiden tilavuudenmuutoksen perusteella. Pohjavesihavainnot osoittivat, että yhdeksän vuoden jaksolla pohjaveden pinta oli laskenut useana kesänä salaojien tasoa syvemmälle mahdollistaen rakenteen muodostumisen ja aineiden liikkumisen makrohuokosia pitkin myös syvimpiin tutkittuihin maahorisontteihin. Maankuivatus oli johtanut rakenteen muodostumiseen koko tutkittuun syvyyteen. Tilavuuspaino pieneni syvemmälle mentäessä, vaikka hiilipitoisuus oli suurin ylimmässä horisontissa. Tulos heijastelee peltomaan kuivumisen aiheuttamaa maan huokostilan irreversiibeliä pienenemistä, kun maasta on poistunut vettä.Varsinkin syvempien horisonttien maa kutistui kuivuessaan melko paljon ja täytti maannosluokittelussa käytettävän Vertic-attribuutin vaatimukset (COLE $>6 \%$ ). Ohutleikkeissä havaittiin paljon maaprofiilissa alaspäin kulkenutta savesta, ja saveksen kertymistä huokosten seinämiin esiintyi vielä salaojien alapuolellakin. Maannos oli Vertic Luvisol (World Reference Base-järjestelmä) ja Vertic Cryaqualf (Soil taxonomy). Näitä maannoksia ei Suomessa ole aiemmin dokumentoitu. 